\title{
ALPORT'S SYNDROME OF FAMILIAL KIDNEY DISEASE WITH DEAFNESS
}

\author{
By
}

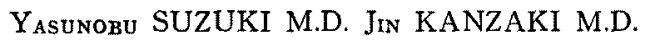

\section{From the Department of Oto-Rhino-Laryngology, School of Medicine, Keio University.}

A Japanese family of an apparent familial kidney disease with hearing loss are presented.

Reports of this syndrome have appeared under different descriptive titles in foreign countries, such as U.S.A., Canada, England, France, Germany, Italy and Israel, but no systemic report has yet been made in Japan. In 1962, the first case report of this syndrome of a family was made by Dr. Sato et al. of Tokyo University, but the details of their studies are not available to us for critical review.

This is the second case in Japan that was seen in the Department of Medicine, Keio University Hospital, Tokyo.

A man, aged 25, was first noted to havc hematuria at the age of 3 years. Deafness was noted at the age of 14. Albuminuria was pointed out at the age of 18 by a doctor and it persisted until he was admitted to a university hospital one and half a month for the investigation and treatment. During the admission, complication of pyelitis and cystitis was seen. A short while after discharge he had a relapse and was admitted to the Depart- ment of Medicine, Keio University Hospital and was reffered to E.N.T. for deafness. He had hematuria and albuminuria at the time of admisson. Renal function was impaired and renal hiopsy clemonstrated foam cells.

Audiometry showed bilaterally a nerve type deafness.

Self-recording threshold audiometry showed the same results. X-ray studies of both ears were normal. TTS was negative. Recruitment appeared to be positive from the tracings in self-recording threshold audiometry. Speech intelligibility was shown as Fig. 5. Vestibular function tests including the examination of positional and positioning nystagmus, writing test and caloric tests were all normal.

The pattern of inheritance of the renal disease (Fig. 1) appears to be due to a dominant gene, but whether it is by a partially sex-linked one or not is yet to be determined. As to the mode of deafness, it seems to be by a recessive gene, but the relation to sex-linkage and renal disease is also not determined.

\section{難聴を伴う家族性腎炎(Alport 症候群)}

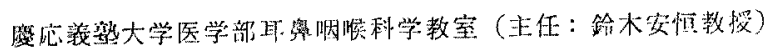

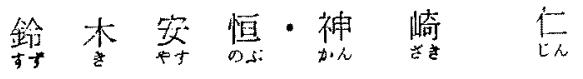

\section{I.はじめに}

Alport 症候样とは1927 年飞家族性腎炎及びこの家系 に灭られる難㯖を詳細に記载した Alport の名をとつた

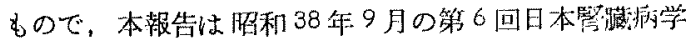
会にて浅野 16)（陵大）等の報告した本邦第 2 例の症例を 主として，可奥科的立場から，遺伝学的考察をも合せて

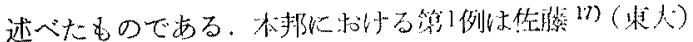

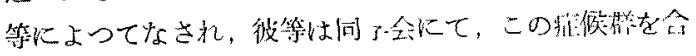

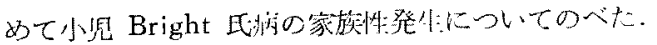

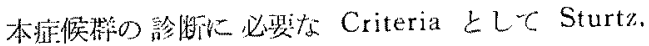
Burke 13) (1956) は次の3つを举げている。すなわち 1）准行性腎疾患の家旅性出現，2)血尿一間歇的血质女 


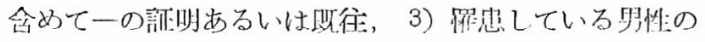
大部分及び女性の若干にみられる神経性、鄚㯖.

\section{II. 症 例}

Y.Y. 男性. 25 才. 患者は 3 才の時腎炎に羅患, 11 才

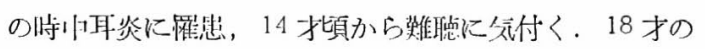

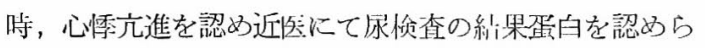
れている。昭和 32 年 5 月から約 1 力月半, 慢性婜炎の

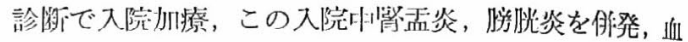
正は最高170位市つた。昭和 38 年 2 月, 再び心情元進, 全身隐总感あり某病院にてやはり慢性腎炎と診断され，

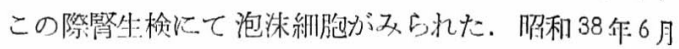

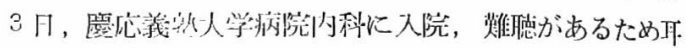

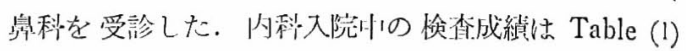
の如くである。

Table 1. 覦查成繦 尿：

\section{掯白 ( $\mathrm{Ht}$ )}

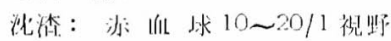

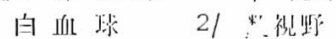

扁平上芚 $2 \sim 3 /$ 全涀野

円 柱 (十)

細菌 (一)

染色グラム陽性球菌

培跉. 白色ブドウ球菌

アルカプトン（一）

チスチン (一)

ピルビン酸 (一)

血液化学

\begin{tabular}{|c|c|}
\hline NPN & $29.0 \mathrm{mg} / \mathrm{dl}$ \\
\hline クレアチニン & $1.6 "$ \\
\hline $\mathrm{Na}$ & $140 \mathrm{mEq} / \mathrm{L}$ \\
\hline $\mathrm{Cl}$ & 107 \\
\hline $\mathrm{K}$ & 4.14 \\
\hline $\mathrm{Ca}$ & 4.71 \\
\hline
\end{tabular}

吅液口氏反応陰性

ASLO 50䋃位.

CRP 娭性

LFT 除州:

价液 :

赤向球 $429 \times 10^{4}$

向拈球 6500

灯帅琵 $81 \%$

II 42

III 30

昵恔球

好陵球

然球 2

リンパ赫夵 15

予贷能

$\begin{array}{ll}\text { G.F.R } & 62 \mathrm{cc} / \mathrm{min} \\ \text { P.S.P } & 15119 \% \\ & 30,32 \%\end{array}$

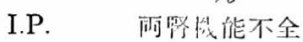
冬生梌：泡沫細胞 (十) 怪学们梌查: 正常 科”：乱, 近祝以外而常

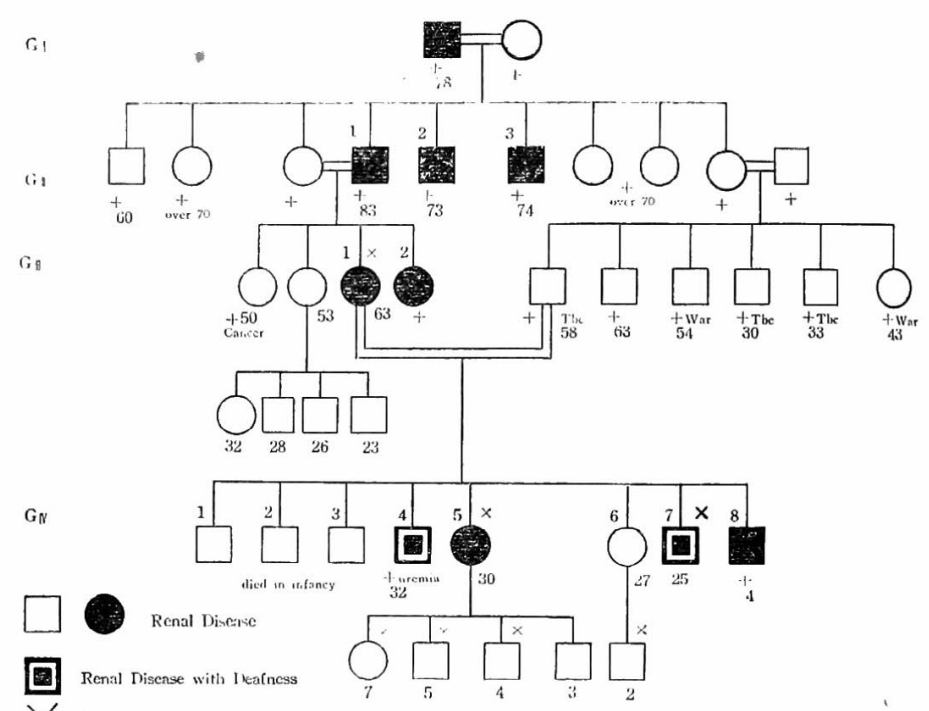

Fig. 1, Family tree of family Y.

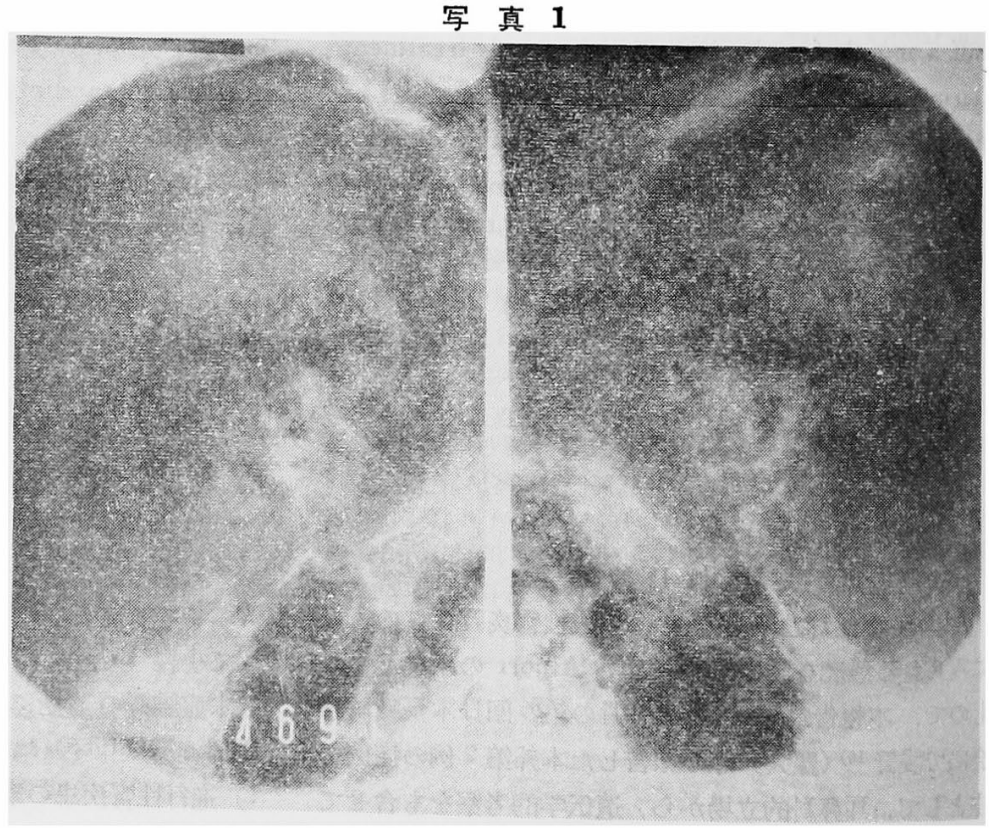




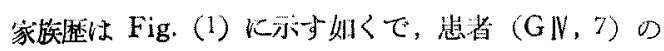
雨䫓はいとこ同志 $(G$ III，1，3）で，患者の兄弟中 3 人 (GN，1，2，3) は幼览期に消化不良にて死亡， 又见 (GN，4) は32 才で䐂請掟にて死亡しているが，生存将:

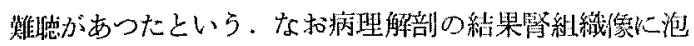

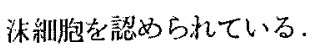

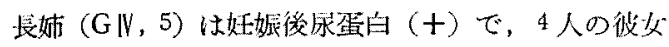
の子供の永娭查には異常を認めなかつた。この長姉及び

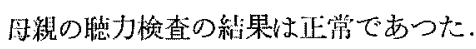

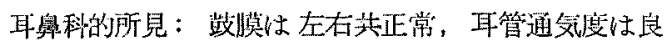
好，奥咽頭正常，耳のレ線写真（写真1）にて子蜂栄の 発青は良好。

オージオグラム (Fig. 2) では気導にて 125〜 500 c/s は左右共 $20 \sim 30 \mathrm{db}, 1000 \sim 8000 \mathrm{c} / \mathrm{s}$ は 40 60db の損
Fig. 2

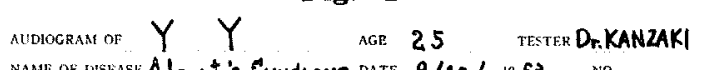
name of disense Alport's Syadrome oate $9 / 10 / 1963$

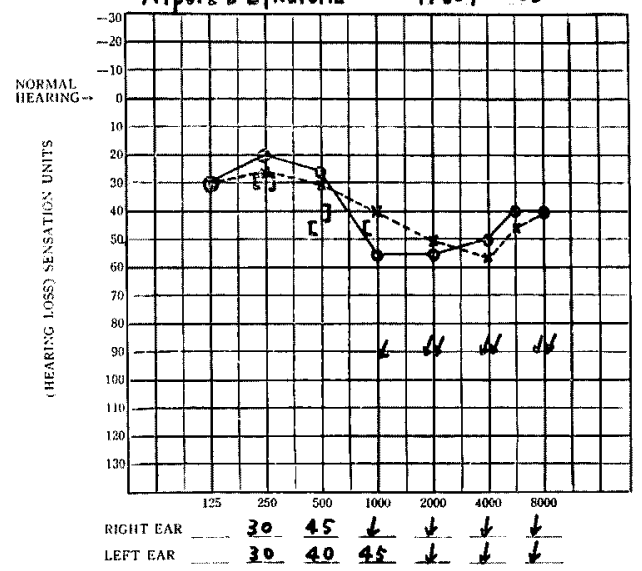

Fig. 3

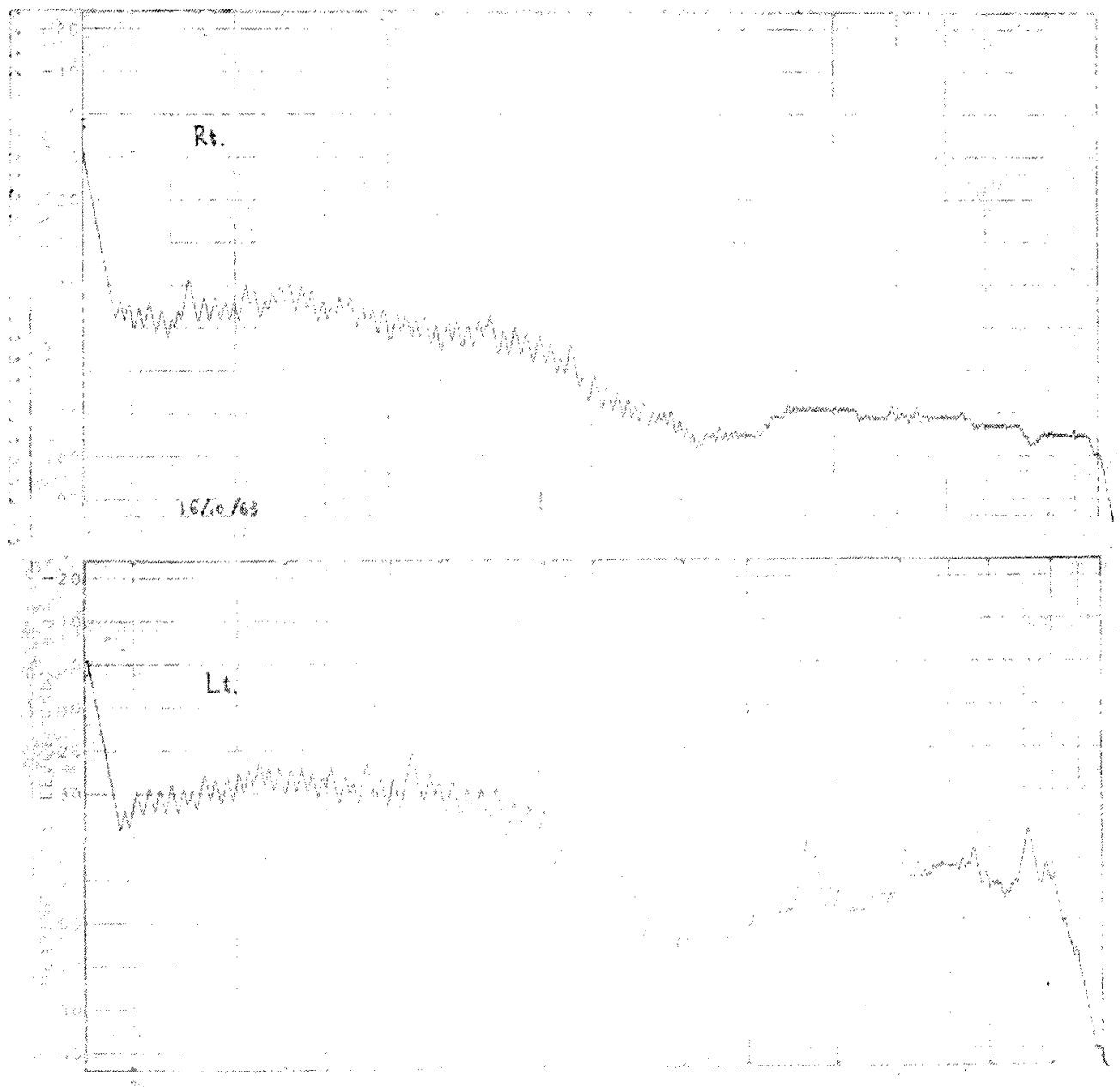




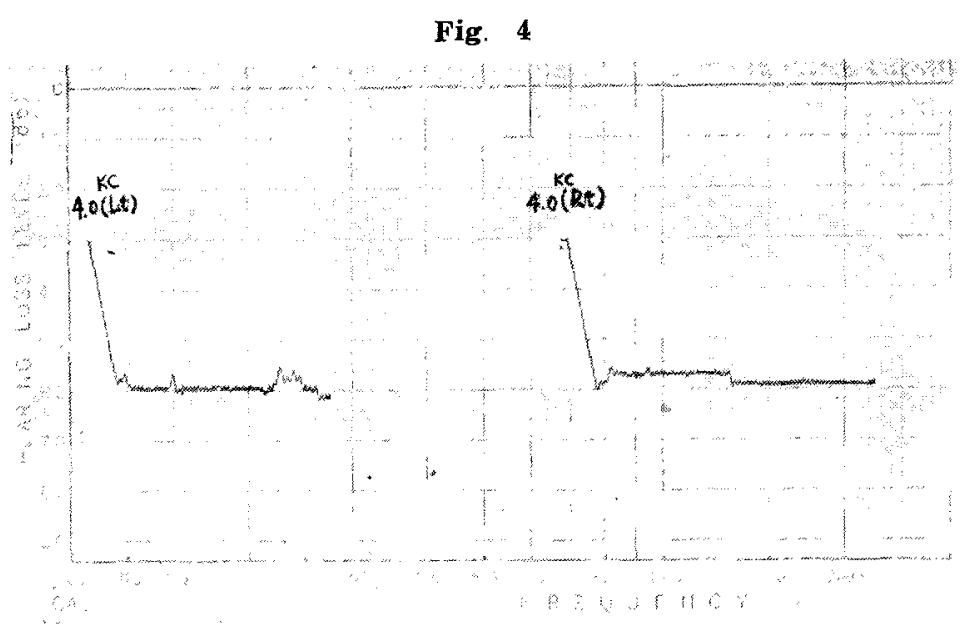

Fig. 5

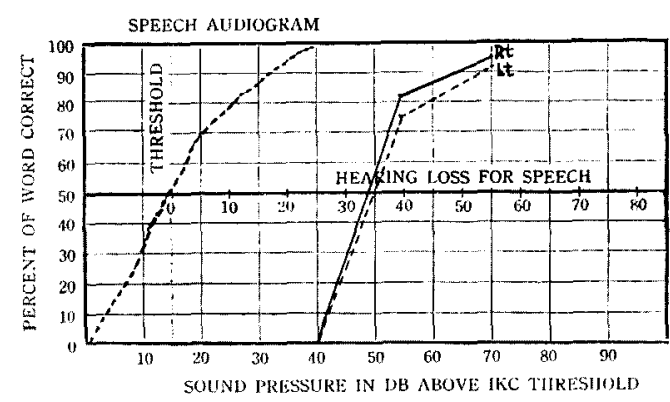

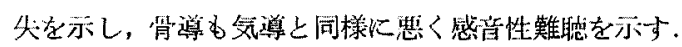
日記オージオメトリーにても同様の結果を示した（Fig.

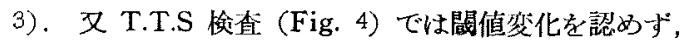
目棓振幅は維小型を示吉。

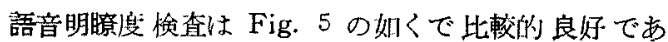
西。

前庭機能検垈ては自癷腿振，顽位眼振，頭位变換腿振 共になく，ロンベルグ現象陰性，歩行試験，書字試験共 K正常. 神絽学的榆查屯正常. 冷温交互陚驗 $\left(30^{\circ} \mathrm{C}\right.$, $44^{\circ} \mathrm{C}$, 各 $20 \mathrm{cc}$ 老 10 秒間比注水) 飞正常, 限科的飞 以乱，近視以外佷底所見に異常を認めない。

\section{III. 考按亚に総括}

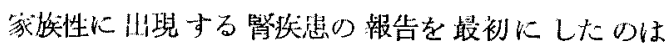
Dickinson 3) (1875) である. 彼は 3 代に亘って調パ 17

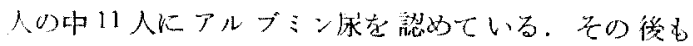
Kidd (1882), Pel (1899), Aitken (1909) 等による旅 台があつたが Guthrie (1902) によつて一家系が報告さ れて以来, 同じ家系から更に症例が Kendall, Hertz
(1912), Hurst (1923) Kより加克ら れ，この家系の最終的報告は・Alpo$\mathrm{rt}^{1)}$ (1927) Кよつてなされた (Fig. 6).

これ等腎疾患の患者に難㯖が伴ら ことのあるのに気付いたのは Fre$\mathrm{nch}(1916)$ 1) で，彼は 2 例の患者を 調べ，これが神経性難㯖であること を示した。この神経性難㯖は明らか

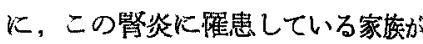
かかり易いもので,これ腎炎，要 るい性血尿のある人济けでなく、こ の家系のこれらの全くない健全な人 にもみられる．この症候群の原因性 未だ不明であり．その遗伝形式も明らかでないので報告 者により色々に乎ばれている、しかし Alport がこの摙 候群の詳緗を最初に記載したので，最近は Alport 䓕候 群として報告されているものが多い。

Fig. 6 Family tree of family reported by Alport (1927). Numerals refer to age in years.

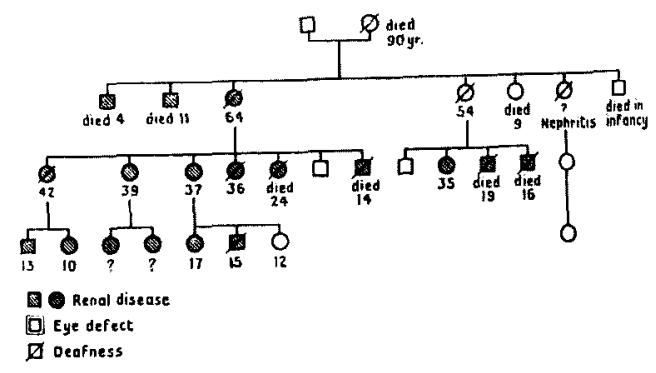

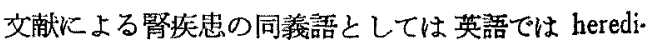
tary familial congenital haemorrhagic nephritis, hereditary interstitial pyelonephritis, hereditary chronic nephritis, hereditary nephritis, congenital heteditary haematuria, idiopathic or congenital hereditary family haematuria 等4) がある.

Alport は Guthrie によつて初め記载された家系を詿 ベて、これに感音性難聴がかなりの頻度にあることを示 した（Fig，6)。即ち，彼は 4 代に亘つて 29 人を謂に 14

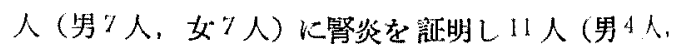
女7人) に感音性難媤を認めた。 その後 1951 年 Perkoff の報告まで 25 年余り，報告がみられなかつたが，過去 
10 年間に 19 家系以上250人以上の罪整者が報告されて いる。これらはアメリカ (Reyersbach 及び Butler 10)， 1954, Sturtz 及び Burke 18)，1956. Russel 及び Smith， 1959. Chappell 及び Kelsey, 1960), カナダ (Goldbloom 5) 他，1957), フランス (Hamburger 等, 1956, Bouchet 及び Paquelin 2), 1956, Morin 他, 1958, Lemoyne 及び Fleury 7), 1962), ドイッ (Nieth ${ }^{8)}$, 1959, Fuhrman, 1959, 19634)), イタリ-(Poli, 1953), イスラェル (Sohar $\left.{ }^{12)}, 1956\right)$, イギリス (Williamson 14)，1961），日本(佐藤“沢田 17)，1962）等である.

本邦の第1 例㤬侁藤, 沢田 (1962) に上つて“進行性 難聴を伴える家族性遗伝性慢性系球体篮炎の1症例”之 して16才の女子を 発端者とする1家系について 報告さ れた，佐藤等は 4 代任亘り 26 人中腎疾患 2 人，難聴者

Table 2. 難聰伴方家族性㹂炎症例の報告

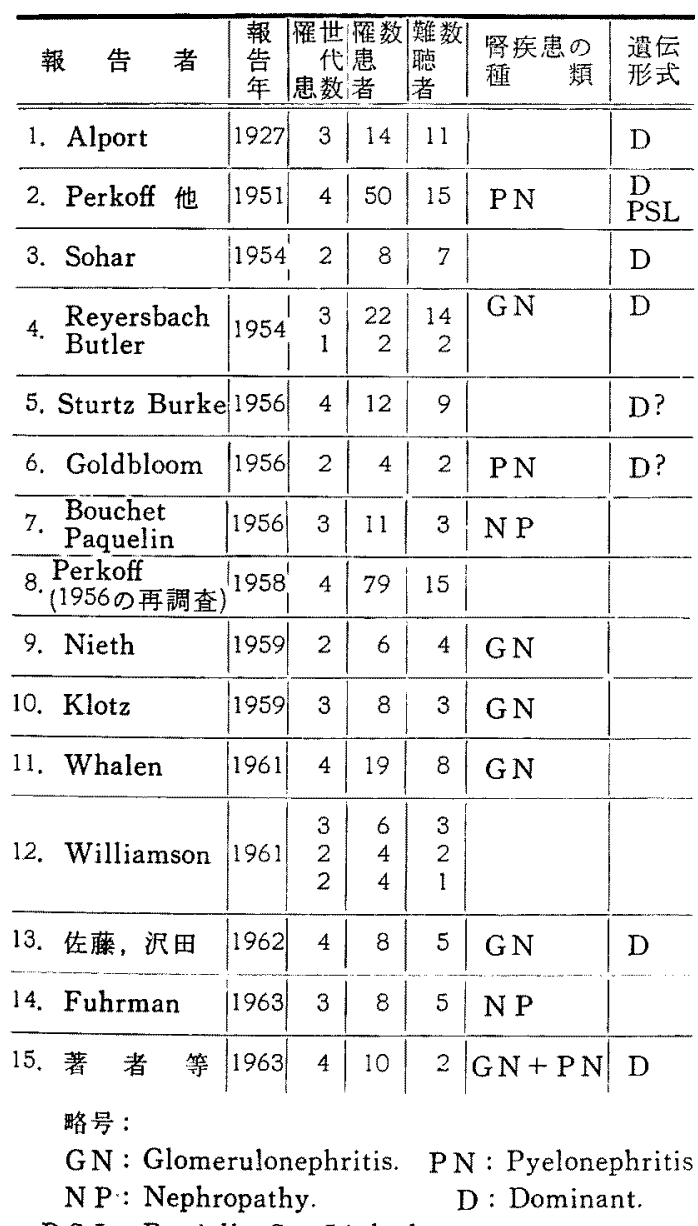

P S L : Partially Sex-Linked
3人，腎疾患と難㯖を有する603人を見出し筲疾患 僈性を示すとした。

健来迄の主な報告は Table 2 の如くでする。

1) 留障害：血尿，蛋白尿が大低約小胃期から，特 は新生時期からみられる。しかし初期には緊機能及び 生検の結果怔常の事が多い，血尿は間歇的のことも り，若干例では細菌尿を示するのもあり，男性でこの

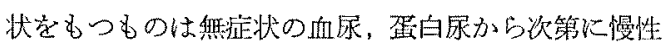
炎に進み，通常進行性で 30 才以前に死亡なることが

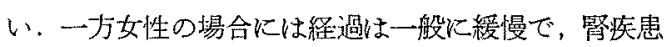

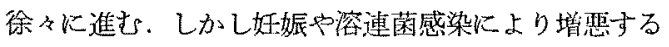
向がある。

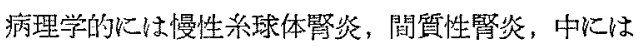

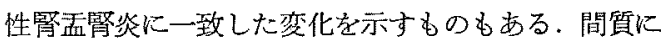
リンパ球が著明に搌潤し又若干例では多数のリポイド

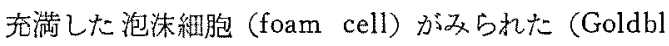
om ${ }^{5)}$ 等, 1957, Perkoff 9) 等, 1958, Castleman 1957

しかし Whalen ${ }^{14)}$ 等は泡沫細胞は家族性ネフロ 一に限らないが，この存在が琶められた時は筩疾患に いての家族歴を精査すべさであるとし，又家族性ネフ パチーの病理所見は根本的には慢性腎炎のそれに極め 類似するが，度々腎䠗炎の像を伴つていると述べて る、これらの病理所見は年令と経過の重症度によつて

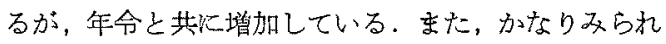
蜸篮炎は恐らく二次的なものと考光られているが， の基礎をなすの慢性糸球体撆炎である。

Robin (1957) 等性部分的伴性媛性遗伝としての䒺

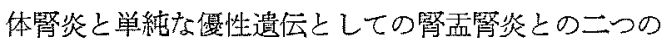
に分け，Loken（1961）等は後者に属する家采を報告 ている。

臨朱椧査では $\gamma$-globulin の娍少と《2-macroglobul

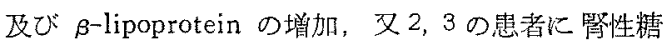
がみられている。

Scriver ${ }^{11)}$ 等は遗伝性简疾患及び難聴の他に腎発育 全, photogenic Epilepsy, アミ/酸代謝傽害を観察 ている. Scriver, Fuhrman ${ }^{4)}$ にり血清尿のタロマ グラフイーでアミノ酸(プロリン・ハイドロキシプロ ン・グリシン) の代謝異常が認められている。

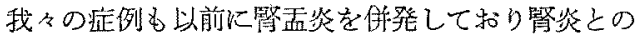
併が考えられる．患者の長兄の病理解剖の等組織像及 密者の婜生检にて得られた繦織像に泡洙絸肥が認めら たことは與味がある。本邦第1例の発端者となつた 才の女子では撉機能，尿洗渣とも9才の時は正常であ 
たか，10才の时に行われた腎生検では系球体の硝子化， 尿管委縮，聞質の細胞浸潤が認められている。この患者 の長兄は 20 才で屎毒症のため死亡しているが腎臓はや はり同様の組織所見を呈した。な和2 例共泡洙細胞はみ とめら机ていない。

我々の症例决てはプロリン・グリシン等のアミ， 酸代謝の異常について検策されなかつたが尿中に了ルカ ブトン, チスチン,ピルビン酸は認めなかつた。な特こ の患者の長姉棌娠後蛋白尿を認めているが，4人の子 供汇は尿所見の異常はみられなかつた。

2）聴力障害及び眼症状：これらの症候群の認められ る家族にはかなり難聴がるられ，それは両側性で感音性 難聴である、これは大部分男性に，筒疾患を伴い，ある い伴わずに現われ，大低10才位で明らか炕なる，又 見潮正正常の聴力のものでもオージオメーターによる 聴力検查で証明し得る難聴者もいる.内耳の組織学的所 見については満足すべき報告は得られていない. Table 3 は Perkoff (1958) 等による腎疾患と難聴の関係を示 したもので 86 人についてオージオィータ一検査が行わ れ(20人の男性, 1 人の女性が高音域に難聴を示した)， 留臓, 聴力共樟害されているのは男 22 人, 女 1 人, 明確な留障害にも拘らず難聴を示さなかつたのは男 2 人，女 22 人，聴力損失の及で等障害のないのは男6人 で女にはみられなからた。

Sohar ${ }^{12)}$ はユダヤ人の 4 人兄弟の聴力を調べ 4 人之 もレクリートメント陽性であつたと報告している。 又

Table 3. Relationship of Nerve Deafness to Renal Abnormalities

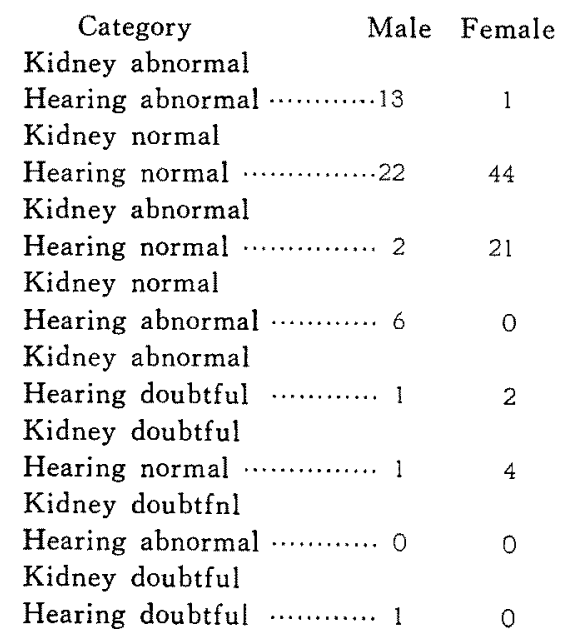

Caloric test, 耳のレ線写真は共に買常を恝めていない， 4 人の中 1 人には慢性腎炎, 難聴の他に腿症状として Cataract と Spherophakia が，別の 1 人には Sphero. phakia のみ，他の 1 人には Cataract がみられている. 又2,3 の家系では眼球欠損が みられたと報告されてい る.

Klotz 6)(1959) は15 才の男子で耳鳴で始まり神経性 難聴を示しホージオグラムで 2 年後に進行性を認めた 1 例を報告している。

Lemoyne は 8 才の男子の腎不全を伴う感音性難缌 の症例を報告し，難㯖は雨耳に対称性に出現し，聴力損 失は C5-cip の型で, レクリートメント現象は認めない とのベている.

Bouchét 2) 等も同樣の家系を報告している. 又 Goldbloom 5)の1例では背腹螖牛神絽核及神経索は正常で あつた，非家族性督疾患に伴万神経性難聴の1例儿迷路 出血がみられた例がある6)，我々の症例のオージオグラ ムはSohar のそれに類似した神経性難聴の像を示し， しかも T.T.S. は認められず，自記オージオーターK よる連続及び固定周波数 $(4000 \mathrm{c} / \mathrm{s})$ にて記録された振 副は縮小型を示す この縮小型がレクリートメントを示 すかどらかについては異論がある，又患者自身の挀克か らも，語音明膫度曲線からも患者は日常会話にそれ程不 自由乙ていないが，多少聞きつらいと感じることがあ り、このため補聴器を装用させた所良結果を得ている。 前庭機能検查は Sohar の報告では Caloric test のみで あつたが, 我々は他に頭位眼振, 頭位変換眼振, 書字試 験歩行試験等を行い，すべてに異常を認めなかつた。

3) 遗伝：Perkoff 9) 等飞よると筲疾患怯部分的伴性 優性遺伝 (partially sex-linked dominant) で他の多 くの著者もこの意見に賛同しているようである．勿諭 $\mathrm{X} \cdot \mathrm{Y}$ 染色体間の交叉る考劣られる. Graham はむしる sex-influenced dominant trait であるとしている ${ }^{14)}$.

又 Goldbloom ${ }^{5)}$ はこの症候群について次の 2 つ可 能性を考慮している. 即ち 1) 胎生発育期の特定の段階

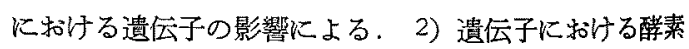
の久如が種々の藏器組織汇障害を及ほすす物質を産生させ る,の2つである。そして前述した如くScriver 等に より本患者のアミ，酸代謝異常が明らがされた. 即ち グリシン。 ハイドロキシプロリンの腎細尿管での再吸扯 の阻書，血清中の L-プロりン濃度の上昇と細尿管での 再吸収がフミノ酸尿をきたすというのである. 又この遗 伝は他の家族性障害之は別個に劣性を示すとした，腎炎 
の遗伝について Fuhrman ${ }^{4)}$ は部分性伴性優性遺伝上り も，むしろ減数分裂の際の異常分噰及び X 染色体と変 異を生ずる Autosom の優先的関係によるとしている.

難㯖の遗伝形式については意見が一致していない Goldbloom 5) は難聴は伴性少性遗伝だとしているが， 腎疾患を生じた同じ遺伝子によるかＸ 染色体の別の遺 伝子に上るか決め難いとし Hamberger 等る同様の見 解を示している。しかし Perkoff は末知の形式ではある が腎疾患に伴っているのではないかと述へている。我々 の調へた家系からも本疾患の遗伝形式について決定的な ことは露い難い.

しかし腎炎は優性であり難聴は劣性であると思われ る、ただ，それらが部分的伴性遗质であるかどらか，あ るいは筜炎と難聴の遗伝子の関係については，はつきり LTW.

4) 予後：男性がこの疾患に雃ると重症で若年者では 度々死に到るまで進行性のことが多い 女性の場合は一 般に経過は緩慢であり腎疾患は徐々に進及，溶連菌感

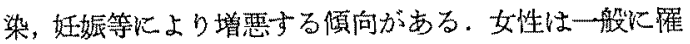
患しても寿命を全うする．男性は䍜患すると20３0才 前に死亡するものが多い、

我々の調べた家系では男性で32才で死亡しているむ のが1人いるが，この家系の発端者になつた患者は 25 才で生存している。な和 GJ，G】 の世代の男性に賢 疾患にて死ししたるのをみるが皆高令まで達している。

\section{IV.むすひ}

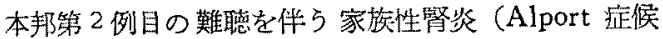
群)について，特に難聴に注目し耳鼻科学的に，又家系 图の分析加ら遗伝学的に考察し文献的考察も加光た，家 系 5 代 37 人中腎疾患 10 人，難聴之筱疾常を有する者 2 名を見た。発端者となつた患者の難聴は14才頃より発 現し，雨側性，対称性の感音性難聴を示した，自記亦一 ジオグラムの振幅の縮小型を直ちにレクリートメントに 結びっけることはできないが TTS (一), 語音明瞭度の 比較的良好なこと等から内耳性難㯖亡考方られる. 前庭 機能には異常を認めなかつた．患者の腎生検の組織像及 び患者の長兄の病理解剖時の腎組織像に泡洙細胞を認め た、遺伝形式については決定的なことは言い、難いが腎疾 患は传性，難聴は劣性遺伝と考えられる。

\section{主要文献}

1) Alport, A.C.: Hereditary familial congenital haemorrhagic nephritis, Brit. med. J., 1: 504, 1927

2) Bouchét, M. et Paquelin: 7) より引用.
Dickinson, W.H.: Diseases of Kidney, Vol. 1:379, 1875. 4) Fuhrman, V.W.: Das Symptome der erblichen Nephropathie mit Innenohrschwerhörigkeit (Alport Syndrom) Dtsch. med. Wshr., 88: 525, 1963. 5) Goldbloom, R.B., Fraser, F.C., Waugh, D., Aronovitch, M., Wiglesworth, F.W.: Hereditary Renal Disease associated with Nerve Deafness and Ocular Lesions, Pediatrics, 20: 241, 1957.

Klotz, R.E.: Congenital Hereditary Kidney Disease and Hearing Loss. A Case History. Arch. Otolaryng., $69: 560,1959$.

7) Lemoyne, J., Fleury, P.: Un nouveau cas de surdité familiale avec néphropathié. Annales d'O-R-L., $79: 599,1962 . \quad$ 8) Nieth, H.: Beitrag zum Syndrom der hereditären Hämaturie, Nephropathie und Schwerhörigkeit. Verh. dtsch. Ges. inn. Med., 65:664, 1959. 9) Perkoff, G.T., Nugent, C.A., Dolwitz, D.A.. Stephens, F.E., Cranes, W.H., Tyler, F.H.: A Follow-Up Study of Hereditary Chronic Nephritis. A.M.A. Arch. intern. Med., 102: 733, 1958. 10) Reyersbach, G., Butler, A.M.: Congenital Hereditary Hematuria. New. Engl. J. Med., 251: 377, 1954. 11) Scriver, C.R., Schafer, I.A., Efron, M.L.: New Renal Tubular Amino-Acid Metabolism. Nature, 192: 672, 1961. 12) Sohar, E.: Renal Disease, Inner Ear Deafness, and Ocular Changes. A.M.A. Arch. intern. Med., 254: 1123, 1956. 13) Sturtz, G.S., Burke, E.C.: Hereditary Hematuria, Nephro. pathy and Deafness. New Engl. J. Med. 254: 1123, 1956. 14) Whalen, R.E., Huang, S., Perschel, E., McIntosh, H.D.: Hereditary Nephropathy, Deafness and Renal Foam Cells. Amer. J. Med., 31: 171, 1961. 15) Williamson, D.A.J.: Alport's Syndrome of Hereditary Nephritis with Deafness. Lancet, 2: 1321，1961，16）线野，他：第6回日本

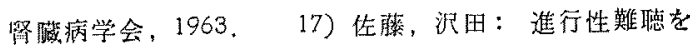
伴光る家族性造伝性慢性系球体腎炎の一应例，小児科診 療, $25: 124,1962$.

稿を終るに当り御援助，御校閲下さつた既大 医学部内科浅野誠一教授，御助言頂いた古賀塺 次郎博士，早㱦弘昆博士に梁謝致します

本詇文の要旨は関東地方会第45回大会にて発 㱔した。

（原稿到着 $=$ 昭和 39.2 .11 日） 